\title{
Pseudozyma pruni sp. nov., a novel ustilaginomycetous anamorphic fungus from flowers in Taiwan
}

\author{
Guey-Yuh Liou, Yu-Hui Wei, Shie-Jea Lin, Chiou-Yen Wen \\ and Fwu-Ling Lee
}

Correspondence

Fwu-Ling Lee

fll@firdi.org.tw

\author{
Bioresource Collection and Research Center (BCRC), Food Industry Research and Development \\ Institute (FIRDI), PO Box 246, Hsinchu 30062, Taiwan, ROC
}

\begin{abstract}
Two ustilaginomycetous anamorphic strains were isolated from flowers in Taiwan. Phylogenetic analysis based on the combined rRNA gene sequence of internal transcribed spacer 1 (ITS1)5.8S-ITS2 and large-subunit D1/D2 domains indicated that the closest recognized species was Pseudozyma fusiformata. The results of DNA-DNA hybridization and physiological characteristics showed that the two strains represent a novel species within the genus Pseudozyma. The name Pseudozyma pruni sp. nov. is proposed, with FIRDI $005^{\top}\left(=\mathrm{BCRC} 34227^{\top}=\mathrm{CBS} 10937^{\top}\right)$ as the type strain.
\end{abstract}

Most species of the genus Ustilago parasitize monocotyledonous hosts and are economically important fungi. A number of anamorphs of Ustilago have been classified into diverse genera (Boekhout et al., 1998). These anamorphic species have been reclassified into the genus Pseudozyma Bandoni emend. Boekhout based on morphological, physiological and biochemical data and partial largesubunit (LSU) rRNA gene sequence analysis (Boekhout, 1995). Pseudozyma species are isolated most frequently from plant materials. Seven species were listed in the genus Pseudozyma by Boekhout \& Fell (1998). More recently, six species were described by Sugita et al. (2003), Wang et al. (2006), Golubev et al. (2007) and Seo et al. (2007). During an investigation of yeast-like fungi in Taiwan, a novel species of the genus Pseudozyma was detected through rRNA gene sequencing of the internal transcribed spacer 1 (ITS1)-5.8S-ITS2 region and the large-subunit (LSU) D1/ D2 domains, and confirmed by DNA-DNA hybridization. Strains FIRDI $005^{\mathrm{T}}\left(=\mathrm{BCRC} 34227^{\mathrm{T}}=\mathrm{CBS} 10937^{\mathrm{T}}\right)$ and 167b (=BCRC 34379) were isolated from flowers in Taiwan by using a method described previously (Wei et al., 2005). Morphological and physiological characteristics were examined by using the methods described by

Abbreviations: ITS, internal transcribed spacer; LSU, large subunit.

The GenBank/EMBL/DDBJ accession numbers for the rRNA gene sequences of the ITS1-5.8S-ITS2 and LSU D1/D2 domains of Pseudozyma pruni FIRDI 005 ${ }^{\top}$ are EU379942 and EU379943, respectively.

A maximum-parsimony phylogenetic tree based on the combined sequences of the rRNA gene ITS region and LSU D1/D2 domain of the novel species and related species, and a table showing the results of DNA-DNA hybridization, are available as supplementary material with the online version of this paper.
Yarrow (1998). Nuclear DNA that was intended for use in PCR was extracted by using a DNeasy Plant Mini kit (Qiagen).

The ITS region and LSU D1/D2 domains of the rRNA gene were defined by using primers ITS5/ITS4 (White et al., 1990) and NL1/NL4 (O'Donnell, 1992). The reaction was performed in a GeneAmp PCR system 9700 (Applied Biosystems), using 30 cycles of the following steps: denaturation at $95{ }^{\circ} \mathrm{C}$ for $30 \mathrm{~s}$, annealing at $55{ }^{\circ} \mathrm{C}$ for $1 \mathrm{~min}$, extension at $72{ }^{\circ} \mathrm{C}$ for $1 \mathrm{~min}$ and a final extension at $72{ }^{\circ} \mathrm{C}$ for $10 \mathrm{~min}$ following cycling. Sequencing reactions were performed by employing an ABI PRISM BigDye Terminator v3.0 Ready Reaction Cycle Sequencing kit as directed by the manufacturer. Finally, the PCR products were sequenced by using an ABI PRISM 3730 DNA Analyzer.

Sequences of each strain were aligned by using CLUSTAL_X 1.83 (Thompson et al., 1997). Ambiguously aligned regions were excluded from the phylogenetic analyses. Phylogenetic evaluation was performed with the PHYLIP 3.63 package (Felsenstein, 2004). Related teleomorphs were selected based on the study by Wang et al. (2006). Phylogenetic trees were constructed by using the neighbour-joining and maximum-parsimony methods. Confidence values for the phylogenetic trees were estimated from bootstrap analyses with 1000 replicates. The trees were viewed by using TreeView 1.6.6 (Page, 1996).

Isolation and purification of DNA for determination of the DNA base composition (expressed as DNA G + C content, mol\%) and for determination of the levels of DNA relatedness were performed with a Genomic DNA Buffer Set and Genomic-tip 500/G (Qiagen). The purified DNA 
was hydrolysed to nucleosides as described by Tamaoka \& Komagata (1984) and the hydrolysate was analysed by reverse-phase HPLC to determine the DNA base composition $(\mathrm{mol} \% \mathrm{G}+\mathrm{C})$. DNA-DNA relatedness values were determined by the photobiotin-labelling microplate method (Lee et al., 1993, 1998). Hybridizations were performed at $47{ }^{\circ} \mathrm{C}$ for $24 \mathrm{~h}$.

The rRNA gene ITS region and the LSU D1/D2 domain sequences of strains FIRDI $005^{\mathrm{T}}$ and $167 \mathrm{~b}$ were identical. The maximum-parsimony tree (see Supplementary Fig. S1, available in IJSEM Online) has the same topology as the neighbour-joining tree (Fig. 1). Phylogenetic analyses revealed that strain FIRDI $005^{\mathrm{T}}$ belongs to the genus Pseudozyma and is located in the anamorphic clade of Ustilago sensu stricto (Stoll et al., 2005; Wang et al., 2006). The closest recognized species was Pseudozyma fusiformata, with strong bootstrap support based on combined alignments of the ITS region and the LSU D1/D2 domain of the
rRNA gene. In the LSU D1/D2 domain, strain FIRDI $005^{\mathrm{T}}$ exhibited $<2 \%$ divergence from seven species, namely Pseudozyma flocculosa (0.9\%), Pseudozyma graminicola $(1.4 \%)$, P. fusiformata (1.8\%), Pseudozyma shanxiensis (1.8\%), Pseudozyma prolifica (1.8\%), Pseudozyma rugulosa $(1.8 \%)$ and Pseudozyma aphidis (1.8\%). In the ITS region, the sequence of strain FIRDI $005^{\mathrm{T}}$ differed by $11.3 \%$ from that of $P$. fusiformata, whereas the differences in the sequences between strain FIRDI $005^{\mathrm{T}}$ and other members of the genus Pseudozyma occurred over $>14 \%$ of the sequence. The sequence difference of the ITS region within a single species is $<1 \%$ in some species of the genus Trichosporon (Sugita et al., 1999) and in Pseudozyma antarctica (Sugita et al., 2003; Wei et al., 2005). The sequence analyses support the distinction between strain FIRDI $005^{\mathrm{T}}$ and the recognized species in the genus Pseudozyma.

Strain FIRDI $005^{\mathrm{T}}$ differed from strain $167 \mathrm{~b}$ in terms of colony morphology and physiological characteristics.

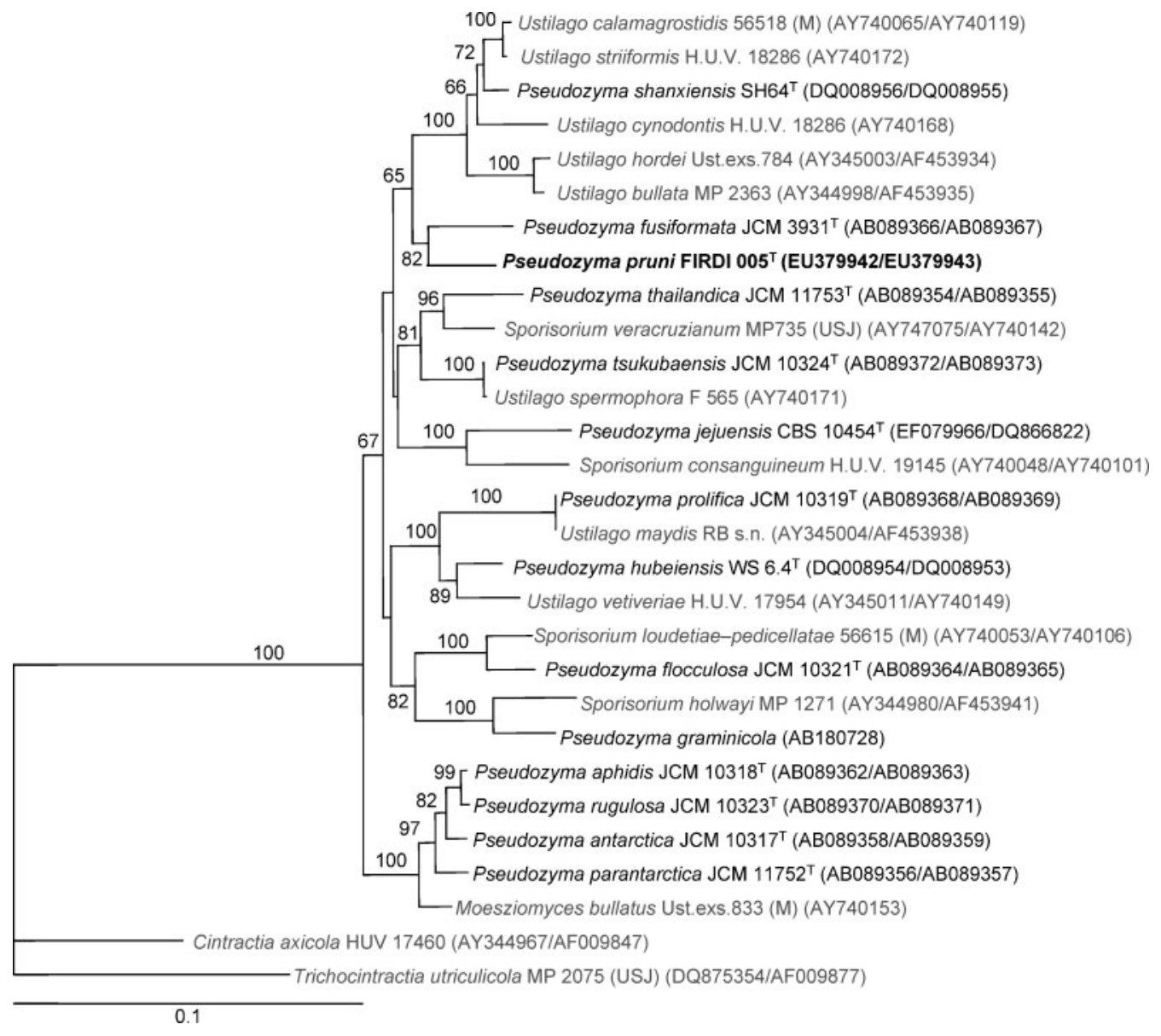

Fig. 1. Neighbour-joining phylogenetic tree of members of the genus Pseudozyma and related teleomorphs, based on the combined sequences of the ITS and LSU rRNA gene D1/D2 domain. The phylogenetic tree was rooted with Cintractia axicola and Trichocintractia utriculicola (Fell et al., 2000). GenBank accession numbers for the sequences used in the analysis are given in parentheses (ITS/LSU rRNA gene D1/D2 domain; single accession numbers indicate sequences that cover both regions). Numbers on branches indicate the confidence level from 1000 bootstrap replicates. Only bootstrap values $>50 \%$ are indicated. Bar, 0.1 substitutions per site. 
Colonies of strain FIRDI $005^{\mathrm{T}}$ were pale orange and friable, whereas colonies of strain $167 \mathrm{~b}$ were white and velutinous. In terms of physiological characteristics, strain FIRDI $005^{\mathrm{T}}$ differed from strain $167 \mathrm{~b}$ in its ability to assimilate ribitol. Strain FIRDI $005^{\mathrm{T}}$ differed from P. fusiformata in the assimilation of galactose, lactose and soluble starch and its growth at $37{ }^{\circ} \mathrm{C}$. Strain FIRDI $005^{\mathrm{T}}$ differed from $P$. flocculosa in the assimilation of lactose and ethanol and its growth at $37{ }^{\circ} \mathrm{C}$ (Table 1). Furthermore, the DNA G+C content of strain FIRDI $005^{\mathrm{T}}$ was $56.2 \mathrm{~mol} \%$, very close to that of $P$. fusiformata (56.1 mol\%). To confirm the relationship of strain FIRDI $005^{\mathrm{T}}$ to $P$. fusiformata and $P$. flocculosa, a DNA-DNA hybridization experiment was performed (see Supplementary Table S1, available in IJSEM Online). Low DNA-DNA hybridization values (13-27\%) were observed between strain FIRDI $005^{\mathrm{T}}, P$. fusiformata BCRC $33869^{\mathrm{T}}\left(=\right.$ CBS $\left.423.96^{\mathrm{T}}\right)$ and P. flocculosa BCRC $33999^{\mathrm{T}}\left(=\mathrm{CBS} 167.88^{\mathrm{T}}\right)$. Therefore, strain FIRDI $005^{\mathrm{T}}$ is considered to represent a novel species of the genus Pseudozyma. This study indicated that the ITS region was a better molecular marker than the LSU D1/D2 domain for the identification of the genus Pseudozyma at the species level.

\section{Latin diagnosis of Pseudozyma pruni G.-Y. Liou, Y.-H. Wei \& F.-L. Lee sp. nov.}

In agaro malti post dies 5 ad $20^{\circ} \mathrm{C}$, cellulae vegetativae ellipsoideae, cylindratae aut fusiformae, 1.1-3.5 ×3.1$10.0 \mu \mathrm{m}$. Pseudomycelia formantur. Fermentatio nulla. Assimilantur glucosum, galactosum, L-sorbosum (infirme), D-ribosum, D-xylosum, L-arabinosum, D-arabinosum (lente), L-rhamnosum (infirme), sucrosum, maltosum, trehalosum, $\alpha$-methyl-D-glucosidum, cellobiosum, salicinum, arbutinum, melibiosum, lactosum, raffinosum, melezitosum, inulinum (infirme), amylum solubile, glycerolum, erythritolum, ribitolum (variabile), xylitolum (lente), L-arabinitolum (lente), Dglucitolum, D-mannitolum, inositolum, D-glucono- $\delta$-lactonum, 2-ketogluconatum (infirme), D-gluconatum (infirme), D-glucuronatum, galacturonatum (infirme), DL-lactatum (infirme), succinatum, citratum (infirme), ethanolum, propanum 1,2 diolum, butanum 2,3 diolum (infirme), quinatum, kalium nitricum, natrium nitrosum, ethylaminum (infirme), L-lysinum, cadaverinum (infirme), creatinum (infirme), creatininum (infirme), D-glucosaminum, imidazolum (infirme), ad crescentiam vitaminum non necessarium est, crescit in medio $0.01 \%$ cycloheximidio addito. Non assimilantur galactitolum, methanolum, saccharatum,

Table 1. Physiological characteristics that differentiate species of the genus Pseudozyma

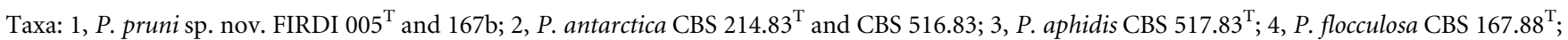
5, P. fusiformata CBS $6951^{\mathrm{T}} ; 6$, P. graminicola VKM Y- $2938^{\mathrm{T}} ; 7$, P. hubeiensis WS $6.4^{\mathrm{T}} ; 8$, P. jejuensis OL71 ${ }^{\mathrm{T}}$; 9 , P. parantarctica DMST $15422^{\mathrm{T}}$; 10, P. prolifica CBS $319.87^{\mathrm{T}}$; 11, P. rugulosa CBS $170.88^{\mathrm{T}}$; 12 , P. shanxiensis SH $64^{\mathrm{T}} ; 13$, P. thailandica DMST $15423^{\mathrm{T}} ; 14, P$. tsukbaensis CBS $6389^{\mathrm{T}}$. The data for P. pruni sp. nov. were from this study; the remaining data were taken from Boekhout \& Fell (1998), Golubev et al. (2007), Seo et al. (2007), Sugita et al. (2003) and Wang et al. (2006). +, Positive; -, negative; L, latent; s, slow positive; w, weakly positive; v, variable.

\begin{tabular}{|c|c|c|c|c|c|c|c|c|c|c|c|c|c|c|}
\hline Characteristic & 1 & 2 & 3 & 4 & 5 & 6 & 7 & 8 & 9 & 10 & 11 & 12 & 13 & 14 \\
\hline \multicolumn{15}{|l|}{ Assimilation of: } \\
\hline Galactose & + & + & + & S & - & S & + & S & + & s & + & + & + & S \\
\hline L-Rhamnose & $\mathrm{w}$ & $\mathrm{V}$ & + & - & - & - & - & - & + & - & + & - & - & - \\
\hline Methyl $\alpha$-D-glucoside & + & + & + & + & + & - & + & - & + & + & + & + & + & + \\
\hline Cellobiose & + & + & S & s & s & $\mathrm{w}$ & + & $\mathrm{L}$ & + & + & S & - & + & + \\
\hline Lactose & + & + & + & - & - & s & + & + & + & + & - & + & - & + \\
\hline Soluble starch & + & + & + & s & - & S & W & + & + & + & + &,$+ \mathrm{w}$ & + & + \\
\hline Erythritol & + & + & + & + & $\mathrm{s}$ & $\mathrm{w}$ & + & S & S & + & S & - & + & + \\
\hline D-Glucitol & + & + & + & + & + & S & + & + & + & + & + &,$+ \mathrm{w}$ & + & - \\
\hline Inositol & + & + & + & + & + & + & - & - & + & + & + & + & + & + \\
\hline D-Mannitol & + & + & + & + & + & S & + & + & + & + & + &,$+ \mathrm{w}$ & + & - \\
\hline Cadaverine & $\mathrm{w}$ & + & + & + & + & + & + & + & + & + & + & + & - & + \\
\hline \multicolumn{15}{|l|}{ Growth: } \\
\hline Without vitamins & + & - & - & + & + & + & + & + & $\mathrm{w}$ & + & - & + & - & S \\
\hline At $37^{\circ} \mathrm{C}$ & + & $\mathrm{V}$ & + & - & - & - & w & + & + & - & + & + & + & + \\
\hline At $40{ }^{\circ} \mathrm{C}$ & - & - & - & - & - & - & - & - & - & - & - & + & - & - \\
\hline
\end{tabular}

${ }^{\star}$ Data from this study. 

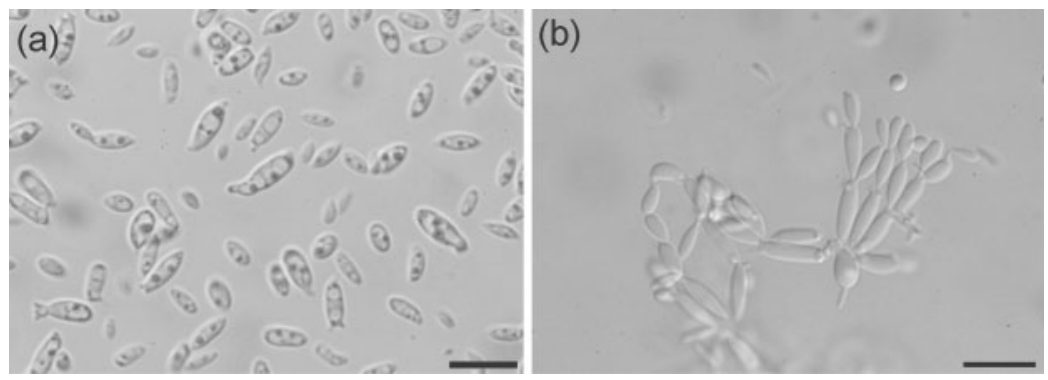

\begin{abstract}
Fig. 2. Pseudozyma pruni FIRDI $005^{\top}$. (a) Blastoconidia in $5 \%$ malt extract broth at $20{ }^{\circ} \mathrm{C}$ for 5 days; (b) blastoconidia in slide culture on $5 \%$ malt extract agar at $20{ }^{\circ} \mathrm{C}$ for 5 days. Bars, $10 \mu \mathrm{m}$.
\end{abstract}

D-galactonatum. In medio $0.1 \%$ cycloheximidio addito non crescit. In medio $50 \%$ glucosum continente non crescit. Augmentum fiunt in temperatura $37{ }^{\circ} \mathrm{C}$. Urea finditur. Amylum non formantur. Diazonium caeruleum B positivum. Proportio molaris guanini+cytosine in acido deoxyribonucleico: $56.2 \mathrm{~mol} \%$ (per HPLC).

Typus: isolatus ex flos Prunus mume Sieb. \& Zucc. ad Tianwei, Changhua, Taiwan, FIRDI $005^{\mathrm{T}}$ (=BCRC $34227^{\mathrm{T}}=\mathrm{CBS}$ $10937^{\mathrm{T}}$ ), depositus in BCRC, FIRDI, Hsinchu, Taiwan.

\section{Description of Pseudozyma pruni G.-Y. Liou, Y.-H. Wei \& F.-L. Lee sp. nov.}

Pseudozyma pruni (pru'ni. L. n. prunus a plum tree, also a botanical genus name; L. gen. n. pruni of Prunus, from which the type strain was isolated).

After 5 days growth on $5 \%$ malt extract agar at $20{ }^{\circ} \mathrm{C}$, colonies are smooth to irregularly wrinkled, somewhat friable or velutinous, pale orange or white and have entire or somewhat eroded margins. Cells are ellipsoidal, cylindrical or fusiform and variable in size $(1.1-3.5 \times 3.1-$ $10.0 \mu \mathrm{m}$ ), some have denticles up to $4.2 \mu \mathrm{m}$, they contain oil droplets (Fig. 2) and pseudohyphae are present. Fermentation is negative. The following compounds are assimilated: glucose, galactose, L-sorbose (weak), D-ribose, D-xylose, L-arabinose, D-arabinose (slow), L-rhamnose (weak), sucrose, maltose, trehalose, methyl $\alpha$-D-glucoside, cellobiose, salicin, arbutin, melibiose, lactose, raffinose, melezitose, inulin (weak), soluble starch, glycerol, erythritol, ribitol (variable), xylitol (slow), L-arabinitol (slow), Dglucitol, D-mannitol, inositol, D-glucono- $\delta$-lactone, 2ketogluconate (weak), D-gluconate (weak), D-glucuronate, D-galacturonate (weak), DL-lactate (weak), succinate, citrate (weak), ethanol, propane 1,2 diol, butane 2,3 diol (weak), quinate, potassium nitrate, sodium nitrite, ethylamine (weak), L-lysine, cadaverine (weak), creatine (weak), creatinine (weak), D-glucosamine, imidazole (weak) and $0.01 \%$ cycloheximide. Vitamins are not necessary for growth. Galactitol, methanol, saccharate, D-galactonate and $0.1 \%$ cycloheximide are not assimilated. No growth is observed in the presence of $50 \%$ glucose. Maximum growth temperature is $37{ }^{\circ} \mathrm{C}$. Urease acivity is positive. Starch-like substance is not produced. Diazonium blue B reaction is positive. $\mathrm{G}+\mathrm{C}$ content of nuclear DNA: $56.2 \mathrm{~mol} \%$ (by HPLC).
The type strain, FIRDI $005^{\mathrm{T}}\left(=\mathrm{BCRC} 34227^{\mathrm{T}}=\mathrm{CBS}\right.$ $10937^{\mathrm{T}}$ ), was isolated from flowers of Prunus mume Sieb. \& Zucc. that were collected at Tianwei, Changhua, Taiwan, on 17 April 1998.

\section{Acknowledgements}

This work was supported by a grant (contract no. 96-EC-17-A-17-R70525) from the Ministry of Economic Affairs in Taiwan. We thank Drs T.-Y. Liu, C.-C. Liao and G.-F. Yuan of FIRDI for their encouragement and revision of the manuscript. Additionally, we thank Dr L.-L. Liaw, FIRDI, for her assistance with DNA sequencing.

\section{References}

Boekhout, T. (1995). Pseudozyma Bandoni emend. Boekhout, a genus for yeast-like anamorphs of Ustilaginales. J Gen Appl Microbiol 41, 359-366.

Boekhout, T. \& Fell, J. W. (1998). Pseudozyma Bandoni emend. Boekhout and a comparison with the yeast state of Ustilago maydis (De Candolle) Corda. In The Yeasts, a Taxonomic Study, 4th edn, pp. 790-797. Edited by C. P. Kurtzman \& J. W. Fell. Amsterdam: Elsevier.

Boekhout, T., Bandoni, R. J., Fell, J. W. \& Kwon-Chung, K. J. (1998). Discussion of teleomorphic and anamorphic genera of heterobasidiomycetous yeasts. In The Yeasts, a Taxonomic Study, 4th edn, pp. 609-625. Edited by C. P. Kurtzman \& J. W. Fell. Amsterdam: Elsevier.

Fell, J. W., Boekhout, T., Fonseca, A., Scorzetti, G. \& StatzellTallman, A. (2000). Biodiversity and systematics of basidiomycetous yeasts as determined by large-subunit rDNA D1/D2 domain sequence analysis. Int J Syst Evol Microbiol 50, 1351-1371.

Felsenstein, J. (2004). PHYLIP (phylogenetic inference package), version 3.6. Distributed by the author. Department of Genome Sciences and Department of Biology, University of Washington, Seattle, WA, USA.

Golubev, W., Sugita, T. \& Golubev, N. (2007). An ustilaginomycetous yeast, Pseudozyma graminicola sp. nov., isolated from the leaves of pasture plants. Mycoscience 48, 29-33.

Lee, F.-L., Lee, C.-F., Okada, S., Uchimura, T., Komagata, K. \& Kozaki, M. (1993). Candida galacta comb. nov., a new combination for Candida apis var. galacta. Int J Syst Bacteriol 43, 183-184.

Lee, F.-L., Fu, H.-M. \& Hsu, W.-H. (1998). DNA hybridization and electrokaryotype study of some Candida species. Int J Syst Bacteriol 48, 1463-1466.

O’Donnell, K. (1992). Ribosomal DNA internal transcribed spacers are highly divergent in the phytopathogenic ascomycete Fusarium sambucinum (Gibberella pulicaris). Curr Genet 22, 213-220. 
Page, R. D. M. (1996). TreeView: an application to display phylogenetic trees on personal computers. Comput Appl Biosci 12, 357-358.

Seo, H.-S., Um, H.-J., Min, J., Rhee, S.-K., Cho, T.-J., Kim, Y.-H. \& Lee, J. (2007). Pseudozyma jejuensis sp. nov., a novel cutinolytic ustilaginomycetous yeast species that is able to degrade plastic waste. FEMS Yeast Res 7, 1035-1045.

Stoll, M., Begerow, D. \& Oberwinkler, F. (2005). Molecular phylogeny of Ustilago, Sporisorium, and related taxa based on combined analysis of rDNA sequences. Mycol Res 109, 342-356.

Sugita, T., Nishikawa, A., Ikeda, R. \& Shinoda, T. (1999). Identification of medically relevant Trichosporon species based on sequences of internal transcribed spacer regions and construction of a database for Trichosporon identification. J Clin Microbiol 37, 1985-1993.

Sugita, T., Takashima, M., Poonwan, N., Mekha, N., Malaithao, K., Thungmuthasawat, B., Prasarn, S., Luangsook, P. \& Kudo, T. (2003). The first isolation of ustilaginomycetous anamorphic yeasts, Pseudozyma species, from patients' blood and a description of two new species: P. parantarctica and P. thailandica. Microbiol Immunol 47, 183-190.

Tamaoka, J. \& Komagata, K. (1984). Determination of DNA base composition by reversed-phase high-performance liquid chromatography. FEMS Microbiol Lett 25, 125-128.
Thompson, J. D., Gibson, T. J., Plewniak, F., Jeanmougin, F. \& Higgins, D. G. (1997). The CLUSTAL_X windows interface: flexible strategies for multiple sequence alignment aided by quality analysis tools. Nucleic Acids Res 25, 4876-4882.

Wang, Q.-M., Jia, J.-H. \& Bai, F.-Y. (2006). Pseudozyma hubeiensis sp. nov. and Pseudozyma shanxiensis sp. nov., novel ustilaginomycetous anamorphic yeast species from plant leaves. Int J Syst Evol Microbiol 56, 289-293.

Wei, Y.-H., Lee, F.-L., Hsu, W.-H., Chen, S.-R., Chen, C.-C., Wen, C.-Y., Lin, S.-J., Chu, W.-S., Yuan, G.-F. \& Liou, G.-Y. (2005). Pseudozyma antarctica in Taiwan: a description based on morphological, physiological and molecular characteristics. Bot Bull Acad Sinica (Taiwan) 46, 223-229.

White, T. J., Bruns, T., Lee, S. \& Taylor, J. (1990). Amplification and direct sequencing of fungal ribosomal RNA genes for phylogenetics. In PCR Protocols: a Guide to Methods and Applications, pp. 315-322. Edited by M. A. Innis, D. H. Gelfand, J. J. Sninsky \& T. J. White. San Diego: Academic Press.

Yarrow, D. (1998). Methods for the isolation, maintenance and identification of yeasts. In The Yeasts, a Taxonomic Study, 4th edn, pp. 77-100. Edited by C. P. Kurtzman \& J. W. Fell. Amsterdam: Elsevier. 